\title{
AUDIT EXEMPTION FOR SMALL AND MEDIUM ENTERPRISES: PERCEPTIONS OF MALAYSIAN AUDITORS
}

\author{
Hasnah Haron $^{\text {* }}$, Ishak Ismail², Yuvaraj Ganesan ${ }^{3}$ and Zulhawati Hamzah ${ }^{4}$ \\ ${ }^{1,2}$ Faculty of Industrial Management, Universiti Malaysia Pahang, \\ 26300 Pahang, Malaysia \\ ${ }^{3}$ Graduate School of Business, Universiti Sains Malaysia, \\ 11800 USM Pulau Pinang, Malaysia \\ ${ }^{4}$ Faculty of Information Technology and Business, \\ UTY Teknologi Yogyakarta, Indonesia \\ *Corresponding author: hasnahharon@ump.edu.my
}

Published online: 30 December 2016

To cite this article: Hasnah, H., Ishak, I., Yuvaraj, G., and Zulhawati, H. (2016). Audit exemption for small and medium enterprises: Perceptions of Malaysian auditors. Asian Academy of Management Journal, 21(2), 153-182. http://dx.doi.org/10.21315/ aamj2016.21.2.7

To link to this article: $\mathrm{http}: / / \mathrm{dx}$.doi.org/10.21315/aamj2016.21.2.7

\begin{abstract}
The objective of the study is to examine audit firm size, the provision of non-audit services (NAS) and audit tenure as factors that influence the likelihood that an auditor agrees with allowing audit exemption. This study employs a $2 \times 2 \times 2$ within-subject experimental design. Respondent auditors were required to evaluate 8 case scenarios. A total of 79 questionnaires were returned and used for data analysis. General Linear Measurement (Repeat Measure) was used to analyse the data. The study found that an audit firm size has a significant impact on the likelihood that an auditor agrees with offering audit exemption. The larger the size of the firm, the greater is the likelihood of agreeing with allowing audit exemption. Therefore, it is suggested that small audit firms (with 5 or fewer employees) merge and focus on activities that contribute more added value such as consultancy. In so doing, auditors from these firms would be required to improve their knowledge and capacity by offering these services and not merely focusing on traditional audit work for SMEs. This is because SMEs are known to have limited resources and capacity and thus would be expected to have poor internal control. The requirement of a mandatory audit for such firms might lead auditors to compromise their independence. Thus, the government
\end{abstract}


and the Malaysian Institute of Accountant (MIA) should help small audit firms to develop the necessary knowledge, skills and competencies to perform non-audit services.

Keywords: audit exemption, SMEs, audit firms, firm size, non-audit services, NAS, audit tenure.

\section{INTRODUCTION}

Many countries, such as Singapore, the United States, the United Kingdom and several other European countries have exempted small companies from annual statutory auditing. The experiences of these countries reveal that non-audit services, such as consultancy and taxation services, increase when the audit exemption was provided. Indirectly, such exemptions encouraged small audit firms to improve their knowledge and skills in these areas and, therefore, led to the growth of the small audit firms and increases in their revenues.

There are several reasons why SMEs have been offered an audit exemption. The 'owner-manager' issue highlights that for the majority of small businesses, the same individuals serves as the directors and the shareholders. In addition, SMEs that are small in size typically lack a strong internal control system, which is a necessary prerequisite for an unqualified or a clean audit opinion. Furthermore, smaller companies regard conventional audits as a costly activity that provides little value added (Collis, 2010; Kamarudin, Abidin, \& Smith, 2012).

In Malaysia, the government is pursuing Vision 2020, a plan intended to move Malaysia from a middle-income economy to a high-income economy. One of the aims of this plan is for companies offering services to improve their service quality by offering value-added services. For audit firms, this would mean offering innovative services other than the traditional audit services such as consultancy and taxation services.

The issue of audit exemption and whether Malaysian regulators are considering the move has been reviewed in the past and leaves both the Small and Medium Practitioners (SMPs) and SMEs with the question of what the outcome of this widely debated issue will be. Among the studies undertaken was a review on the requirement of mandatory audit for all companies. In early 2009, the Corporate Law Reform Committee issued a recommendation to retain mandatory audit for all companies, but power would be given to the regulator to exempt small companies from this requirement (SSM, 2009). If audit was deregulated, audit firms which concentrated on audit work for small companies would be affected. Thus far, there 
has been no strong indication or proposal regarding the elimination of mandatory audits. Considering the progress made in other countries in audit deregulation, including in neighbouring Singapore, the auditing industry in Malaysia will remain status quo until policymakers perceive a need to change the regulations on statutory audits. Md. Ali, Sahdan, Harun Rasit, and Teck (2008) stated that the Malaysian auditing industry is "intertwined" with the dynamics of the political and socioeconomic context. Culture represents another potential influence on Malaysia's accounting and auditing practices. Haniffa (2006) contended that cultural factors were a prominent factor, as the traditions of a nation are instilled in its people, and this could explain "why things are the way they are".

Little research has been conducted to evaluate the role of small and medium practices (SMPs) as 'expert advisors' to support the business activities of small and medium enterprises (SMEs) over and above providing a statutory audit. These circumstances have led to conflict because auditors are attempting to maintain their professional standards while simultaneously considering the wishes of their clients (Koo \& Sim, 1999).

The potential advantages of audit deregulation would include allowing SMPs to focus their resources on developing their capacities and professional capabilities in niche areas other than statutory auditing to serve the heterogeneous SMEs segment. SMPs with the ability to provide SMEs with a broad range of business consultancy services and expand these services beyond the traditional mandatory audit work will spur growth in both entities. Relationship building between the SMEs and SMPs is considered crucial in the long run (Abang, 2013; Haron, Ismail, Yahya, Khalid, \& Ganesan, 2010). There is a distinction between SMEs (non-listed) and publicly listed companies. Publicly listed firms face scrutiny from stock exchanges, regulators and market participants, and they are characterised by the separation of ownership and control. SMEs, in contrast, are much less regulated. The disposition of their agency problems is different as they are less exposed to market forces, publicity, and litigation and they operate in a much less regulated environment. Due to differences in market dynamics, there are different market segments for audit services for listed and large companies and those for SMEs. Requiring statutory audits of SMEs appears to be questionable based on the characteristics of SMEs and SMPs. As Tabone and Baldacchino (2003, p. 388) explained, 'the conventional focus when evaluating the need for a statutory audit requirement is the economic size of the company'. Limited research has been conducted to evaluate audit firms' role as 'expert advisors' providing business support services to SMEs over and above statutory audits. This situation generates conflict because auditors attempt to maintain their professional standards while 
simultaneously considering the wishes of their clients (Koo \& Sim, 1999). As Langli and Svanström (2013, p. 7) affirmed, 'the differences that exist between private and public firms are so large that we cannot rely on findings for public firms without careful consideration when we want to understand auditing in private firms, whether auditing is statutory or not.'

In recent decades, various studies such as Abu Bakar and Ahmad (2009); Amake and Okafor (2012); Hariri (2009); Shockley (1981) were conducted on auditing and the perception of auditor independence. These studies also examined independence issues based on a variety of respondents, ranging from the preparers and users of financial statements to cross-cultural studies on perceptions of the auditor independence. Furthermore, scholars had examined the various factors that influence the perceived independence issue and also obtained mixed findings. To our knowledge, very few empirical studies have been conducted on Malaysia to examine the factors leading to auditors' perceptions of allowing audit exemptions. Therefore, the aim of this study is to close the gap by examining auditor's perceptions regarding audit exemption. Small businesses face constraints with respect to their internal control systems that will affect the auditor's opinion. Thus, if auditors were asked to issue an audit opinion on the company's financial statements, this would affect the auditor's independence. Thus, this study regards agreement with the proposition of providing an audit exemption for SMEs as indicating that the auditors would be more independent in performing their audit work.

The lack of literature on auditing SMEs in the Malaysian context entails a gap in the body of knowledge regarding the need for an audit exemption for SMEs from an SMP perspective. Furthermore, this study represents an important contribution because Malaysia is the only Asian country that requires all private companies, regardless of size, to have annual audits of their accounts annually (Salleh, Che Rose, Kumar, \& Jaafar, 2008a). Therefore, the objective of this research is to investigate the factors influencing the likelihood that auditors will agree to an audit exemption for SMEs using an experimental research design. This study will specifically examine audit firm size; the provision of NAS; and the length of the relationship between audit firms and their clients (audit tenure) and the effects of these factors on the likelihood of an auditor agreeing with providing an audit exemption. The next section will present the literature review and hypothesis development include the types of companies and regulations in Malaysia, the background of audit exemption and the relationship between SMEs and auditing. 


\section{LITERATURE REVIEW AND HYPOTHESIS DEVELOPMENT}

\section{SMEs in Malaysia}

In Malaysia, section 174 of the Companies Act of 1965 states that all registered companies, regardless of size, type of business, or whether the company is public or private, must have their financial statements audited on an annual basis. The financial statements must be prepared in accordance with the accounting standards approved by the Malaysian Accounting Standards Board (MASB) and the provisions of the Companies Act of 1965 and audited by an approved auditor. The types of companies in Malaysia are Public Listed, Non-Public Listed, Private Limited and Exempt Private Companies. Other than Exempt Private Companies, all companies must file audited accounts with the Companies Commission of Malaysia (CCM).

In Malaysia, SMEs in the manufacturing sector are defined as enterprises with annual sales turnover of no more than RM50 million or employing no more than 200 workers, whereas in the services and other sectors, the company must have annual sales turnover below RM20 million or employ no more than 75 workers. According to Economic Census 2011, the types of legal status of SMEs are namely: (i) Individual Proprietorship (71\%), (ii) Partnership (8.5\%), (iii) Private Limited Company (18.4\%), and (iv) Others (2.1\%). Private limited companies account for the second largest portion of SMEs in Malaysia. As the name suggests, a private limited company's shares are privately held by its shareholders and are not available to the public. A private limited company, identified by the abbreviation 'Sdn Bhd' (Sendirian Berhad) at the end of the company's name, is regulated by the statutory requirements for companies incorporated under the Companies Act of 1965 and thus must have its accounts audited.

Generally, the objective of an audit is to express an opinion on the truth and fairness of a company's financial statements in accordance with the requirements of the Companies Act of 1965. In other words, the fundamental purpose of an audit is to inform shareholders regarding the management of the company. However, many private limited companies are owner- or family-managed and small, as measured by quantitative criteria such as turnover, net assets and/or the number of employees. Typically, the ownership and management of the company's assets are vested in the same persons. This leads to the question of whether a mandatory annual statutory audit requirement is justified in such circumstances, 'where the auditor is merely reporting information already known to the same person acting in a different role' (Tabone \& Baldacchino, 2003, p. 389). The relevance of a mandatory annual statutory audit requirement for SMEs, given their economic 
size, owner-managed status and costly reporting requirements, has been the subject of substantial debate worldwide.

In the year 2002, 91\% of audit firms in Malaysia are owned by one or two partners, whereas $1 \%$ of these firms have more than nine partners (Lee, 2002). Surail, Ayoib, and Hariri (2007) concluded that the Malaysian market for audit services is competitive and 'the survival of small and medium practitioners hinges on the provision of personalized services to clients' (Lee, 2002, p. 16).

In a presentation by Audit Oversight Board Malaysia on November 2014 entitled "Sectorial Dialogue with Audit Firms", it can be said that although the number of small audit firms with either sole proprietor or with 2-4 partners are decreasing in number from 2011 to 2014, it can be seen that they are still the majority of audit firms in Malaysia from 2011 to 2014, totalling 81\%,77\%, 74\% and 74\% respectively. This can be seen in Table 1 .

Table 1

Number and types of audit firms in Malaysia

\begin{tabular}{|c|c|c|c|c|c|c|c|c|c|}
\hline \multicolumn{2}{|c|}{ Profile of audit firms/ } & \multicolumn{8}{|c|}{ No. of Audit Firms } \\
\hline Year & & \multicolumn{2}{|c|}{2011} & \multicolumn{2}{|c|}{2012} & \multicolumn{2}{|c|}{2013} & \multicolumn{2}{|c|}{$\begin{array}{c}\text { Half Year } \\
2014\end{array}$} \\
\hline Qty & & Qty & $\%$ & Qty & $\%$ & Qty & $\%$ & Qty & $\%$ \\
\hline Big Firms & $\begin{array}{l}10 \text { partners and } \\
\text { above }\end{array}$ & 6 & 8 & 6 & 9 & 8 & 15 & 8 & 15 \\
\hline $\begin{array}{l}\text { Medium Size } \\
\text { Firms }\end{array}$ & 5-9 partners & 8 & 11 & 9 & 14 & 6 & 11 & 6 & 12 \\
\hline \multirow[t]{2}{*}{ Small Firms } & 2-4 partners & 48 & 64 & 43 & 64 & 36 & 68 & 35 & 67 \\
\hline & Sole proprietors & 13 & 17 & 9 & 13 & 3 & 6 & 3 & 6 \\
\hline TOTAL & & 75 & 100 & 67 & 100 & 53 & 100 & 52 & 100 \\
\hline
\end{tabular}

Source: Audit Oversight Board, 2014. Retreived on 1 December 2015 from http://www.sc.com.my

\section{Background of Audit Exemption}

Audit exemption is an apparent issue and has been frequently discussed in the auditing industry. The issue has been raised and addressed in many developed countries such as the UK, Australia and New Zealand (Kamarudin, et al., 2012). Other countries have deregulated audits for SMEs, including Malaysia's neighbour Singapore, the United Kingdom (UK), Australia, New Zealand, Canada and European Union (EU) countries. 
SMEs have been exempt from mandatory auditing in Australia since 1971. In 2003, Singapore adopted Australia's stringent model to qualify companies for audit exemption (Chan, 2012). Canada and the UK introduced audit exemptions in 1994. The UK government has made several changes to the qualifying threshold for businesses to be exempted from auditing. Most countries have implemented other provisions to protect the interests of shareholders and other stakeholders despite the companies satisfying the threshold criteria. In the US, privately owned companies are not legally required to conduct audits. In general, audit exemption is given to SMEs due to several reasons such as SME's lack of internal control system due to the fact that they are managed by a limited number of staff and that owners are usually also the managers of the company. Thus, in most of the small companies where the shareholders and the directors are the same person, it would make auditing meaningless. In addition, audit fees that SMEs would have to pay would be a financial burden for the small companies with no benefits in return for the company. (Collis, 2010; Kamarudin, et al., 2012; Salleh, Che Rose, Kumar, \& Jaafar, 2008b)

This issue has never been addressed in regulatory reform despite several fundamental surveys and studies conducted by the Corporate Law Reform Committee (CLRC) beginning in 2003 (Chan, 2012). In a study conducted by Chung and Narasimhan (2001), small companies supported the elimination of mandatory audits and audit fees. These small companies believed that an audit exemption would reduce the workload of directors and staff involved in the preparation of annual audits. Few studies have been conducted on the topic in the Malaysian context. However, numerous studies have been performed in countries that have implemented deregulation, especially in the United Kingdom (UK) and European Union (EU). Studies conducted in the UK offered useful insights for policy makers to effect change based on the characteristics of small companies (Beaver \& Prince, 2004; Collis, 2010; Collis \& Jarvis, 2002). A certain revenue threshold for the companies that is eligible for exemption from annual audit can be determined.

Chan (2012) noted that the study on audit exemption in Malaysia based on the auditors' perceptions is Salleh, et al. (2008a). Salleh, et al. (2008a) examined the auditors' perceptions on eliminating mandatory annual audits and found that, in general, auditors in Malaysia are opposed to the audit exemption regulation. The authors also found that the primary contributors to audit firm revenue were audits conducted for SMEs. The authors further found that auditors perceived that SMEs derive substantial benefits from having their accounts audited. These benefits include fraud detection and improved decision making (Salleh, et al., 2008a). Collis (2010) contended that it is the management's responsibility to weigh the costs and benefits of financial reporting and that it is logical to assume that 
such decisions are made based on economic rationality. Power (1997, p. 5) stated: 'Audit is a risk reduction practice'. On this basis, Collis (2010) further explained that an audit serves as a mechanism to reduce information risk, inherent risk and control risk and, ultimately, agency costs.

Based on previous studies on audits of SMEs, there is no consensus among regulators regarding the need for statutory audits of private firms (Langli \& Svanström, 2013). In the US and Japan, private firms operate without any legal requirement to disclose financial statements (Arruñada, 2011). The legal requirements for audits differ across the EU countries. For example in Denmark, Sweden and Malta, all firms are required to prepare audited financial statements, including those with no sales, whereas Cyprus, the Netherlands, Germany and the UK only require auditing for firms with sales exceeding 7 million euros (Collis, 2010).

Although previous research have concluded factors such as providing non-audit services (NAS), the duration of auditor-client relationship (audit tenure), audit market competition, the size of audit firm/audit client, the size of audit fee, the existence of audit committee, the client's financial condition, gift, discount on purchases and nature of conflict can influence perceived auditors' independence. This study, however, will focus only on three of those factors which are opined to be relatively important factors in influencing auditors' independence: (i) size of audit firm; (ii) provision of non-audit services by audit firms to the audit clients, and (iii) tenure of audit firms serving the needs of a given client. This is in line with the MIA By-Laws which highlighted that threats to independence are caused by self-interest, self-review, advocacy, familiarity and intimidation. These threats appeared in many circumstances such as in providing non-audit services, duration on auditor-client relationship (audit tenure) and audit firm size. This shows that the three factors are perceived to be influential by the regulators. For example, the duration of auditor-client relationship or audit tenure expose auditors to not familiarity, but also self-interest and self-review threat. In addition, providing nonaudit service may expose auditors to all the possible threats.

\section{Small and Medium Enterprises and Auditing}

From a theoretical perspective, the need for auditing concerns Agency Theory and Stewardship Theory. Agency Theory concerns companies for which there is a separation between ownership and control. To monitor the activities of managers, the principal (owner) must be willing to incur monitoring costs (Jensen \& Meckling, 1976). Stewardship Theory notes that managers hired by the owner must serve the interests of the owners (Donaldson \& Davis, 1991). Thus, management can be monitored through the annual accounts, the reliability of which is enhanced by 
an audit report (Goddard \& Masters, 2000). However, in many private limited companies in Malaysia, the owner (shareholders) and manager is the same person. Prior studies indicated that a statutory audit requirement does not provide much value in this context (Kamarudin, et al., 2012; Tabone \& Baldacchino, 2003). Beaver and Prince (2004) examined management issues among small firms in the UK and concluded that the form of ownership that exists in larger organisations, which is usually distanced from its management and control, is not found in the case of small enterprises. Tabone and Baldacchino (2003) analysed mandatory annual statutory audit requirements for owner- managed companies in Malta. They concluded that in an "owner-managed" company, statutory audits cannot be understood as monitoring in the sense of the traditional agency relationship between shareholders and directors because the relationship does not exist.

Chan (2012) and Kamarudin, et al. (2012) found that the financial information contained in SMEs' financial reports did not satisfy the requirements of the reports' primary users. This suggests that the primary deficiencies of SME financial statements are that they were prepared for tax reasons, using out-of-date information and with limited disclosure. Therefore, SMEs' financial statements were prepared merely to satisfy statutory requirements. Furthermore, the majority of SMEs engage in simple business transactions, and non-compliance with mandatory accounting standards is prevalent among SMEs (Goddard \& Masters, 2000).

As in previous studies, SMEs that do not believe that they benefit from statutory audits welcome the implementation of audit exemptions. Kamarudin, et al. (2012) observed a significant relationship between the level of acceptance of audit exemptions and the perceptions of the value provided by an audit, audit burdens and audit costs among SMEs in Malaysia. Further insights from the SMEs include the fact that statutory audits are not considered to be of substantial value in the Malaysian market, where most companies have them performed for the sake of regulatory compliance. Previous research have examined whether the benefits of audit outweigh the costs (Collis, 2010; Farrugia \& Baldacchino, 2005; Salleh, et al., 2008a). For example, the benefits of annual auditing are that it can help to detect fraud, value-added services to the companies, assist the management in the decision making process, and give confidence to third parties about the financial status of the company. In contrast, the audit exemption for SMEs in the UK was intended to reduce the burden of compliance for small companies, as for firms below a certain size, the costs of auditing outweigh the benefits (Collis, 2010).

Meanwhile, accountability and internal control within SMEs are often the primary concerns associated with audit deregulation. Moreover, the interests of users of audited financial statements should always be the priority of companies and be 
protected. Studies conducted on SMEs in Malaysia regarding their perceptions of the fundamental purpose of audits (prepare and publish their financial statements) indicate that SMEs generally have audits conducted to satisfy statutory requirements (Chan, 2012; Kamarudin, et al., 2012). Most SMEs rely on their accountants to satisfy these reporting obligations. In addition to providing auditing services to SMEs, SMPs also provide credibility for published accounting information among users of financial statements, for example, to facilitate the on-time and accurate payment of taxes, thereby avoiding penalties, interest and investigations. Furthermore, SMPs also provide advisory services to improve the business funding, play a key role in raising finance and capital, improve controls, deter and detect material fraud and error, demonstrate good corporate citizenship and other ancillary benefits of an audit such as advice regarding the structure and operations of systems. Some SME directors do not regard reporting costs as an undue burden. SME directors regard tax authorities and the organisation's management and lenders as the most important users of audited financial statements.

It is necessary to protect the users of financial statements and creditors. Tabone and Baldacchino (2003) reported the significance of a statutory audit requirement in the owner- manager context if the audit report is relevant to third parties such as bankers and other creditors and tax authorities and if the statutory audit has a positive effect on the owner- manager and staff in the form of imposing financial discipline (and not particularly for fraud detection or error finding) and providing advice in non-audit areas. Banks and lenders require audited financial statements as part of the credit assessment process for loan applications and during the loan tenure, as well as when deemed necessary (Kamarudin, et al., 2012). Therefore, the interests of creditors concerning audit exemption must to be taken into consideration. Stringent criteria are imposed in countries such as Canada and Australia to protect the interests of stakeholders (Chan, 2012). In addition, SMEs' access to finance tends to be determined, more than other factors, by the quality of financial information they can produce and the degree to which individuals, institutions and governments are willing to take on the risk of financing them (ACCA, 2010).

The positions of other stakeholders are vital when considering audit exemption. The stakeholders most affected by reforms of audit requirements are the SMPs, banking institutions and other third-party users of SMEs' audited financial statements (Langli \& Svanström, 2013). Regulators need to ensure that procedures are in place to protect the minority shareholders and other stakeholders in the company. 


\section{Audit Firm Size}

Previous research suggests a positive association between audit firm size with auditor independence (Abu Bakar, Abdul Rahman, \& Abdul Rashid, 2005; Abu Bakar \& Ahmad, 2009; DeAngelo, 1981; Gul, 1989; Shockley, 1981). It has been found that larger audit firms has higher auditor's independence as they are often considered to be more able to resist pressures from management compared to small audit firms. More to the point, it has been argued that certain characteristics of small audit practices may increase the impairment of independence, such as having the tendency to provide a more personalized mode of service and close relationship with the client (Shockley, 1981). It is often recognized that large auditing firms are less dependent on any single client who are able to resist client firm pressure as they. However, as pointed out by (Goldman \& Barlev, 1975), one should not conclude that large CPA firms are immune to pressures from their clients. The court cases which challenge the assumption that CPA firms acted independently indicate that a large CPA firm is no guarantee of its ability to resist pressures from clients, as the case with Arthur Andersen and Enron (Abu Bakar \& Ahmad, 2009). In Malaysia, Salleh, Che Rose, Kumar, and Lu (2007) mentioned that 98.5\% of MIA firm members are made up of small firms, having one to five partners. Another view with regards to the size of audit firms in Malaysia, Abu Bakar and Ahmad (2009), mentioned that $91.4 \%$ of Malaysian audit firms fall into the category of small firms with one to two partners, while medium size audit firms with three to eight partners constitute $7.5 \%$ of the population of audit firms and the remaining figure of $1.1 \%$ are of the large size audit firms with more than nine partners. Salleh, et al. (2008a) used three factors that are being used in the SMEs definitions to categorize the firm size. The factors were paid-up share capital, number of employees and annual turnover. The current study will adopt the measurement for audit firm size based on the SMEs criteria to classify services and other sectors by sizes according to number of employees. Therefore audit firm sizes are categorised into two, namely an audit firm size having less than five employees (micro) and one with more than five employees (small/medium).

\section{Non-Audit Services}

NAS as defined by Firth (1997) include tax consultancy, system consultancy, management advice, international business advice, human resources management and investment consultancy. Other than providing audit services, many audit firms provide NAS to their audit clients. The joint provision of audit and nonaudit services (NAS) by incumbent auditors has been intensively debated in the literature. The AICPA has repeatedly taken the position that independence is not necessarily impaired when a CPA performs NAS for his audit clients (Beattie 
\& Fearnley, 2002). However, auditors sometimes provide other services that are related to audit that is different from NAS. A study by McKinley, Pany, and Reckers (1985) examined whether provision of NAS by audit firm, audit firm type and audit firm size would affect bank officers' perceptions of CPA independence, the financial statement reliability and their loan decision. Results showed that NAS did not affect the recommendations of loan application and the reliability of financial statements. Meanwhile the studies by Hariri (2009), Shockley (1981), and Abu Bakar and Ahmad (2009) have found that NAS significantly impair audit independence. Various measurements of non-audit service is evident from the past studies. Earlier research by Shockley (1981) merely measured whether or not auditors provide such services to their clients, as indicated in the scenario to be 'yes' (Y) or 'no' (N) and Abu Bakar, et al. (2005) who later replicated her research used the same measures. In a more recent research, as cited in Hariri (2009), Dopuch, King, and Schwartz (2003) segregated his measurement to be "Provide" (disclose, not disclose) and "Not Provide", which is similar. The MIA By-Law cut off point for non-audit service fee is not to exceed $15 \%$ of the audit firm's total revenue, however the MIA By-Law does not state a maximum limit for NAS received from a single client. However this study defines non-audit service as 'present' or 'absent', that is the current study will segregate the provision of NAS to its clients into two levels, either 'Provide NAS'or 'Do not provide NAS'.

\section{Audit Tenure}

Tenure is the number of years an auditor audits a client. Audit tenure is said to have an influence on auditor independence. A long tenure is said to have a negative effect on auditor independence as many, especially regulators, have the impression that the client can better influence his auditor in a longer auditor-client relationship as compared to a shorter relationship. An auditor is perceived to be inclined toward his client through the years as they become familiar to each other. Hence, longer audit tenure is viewed to be a threat on auditors' independence. On the other hand, a shorter tenure is perceived to be able to overcome the threat. As auditor-client relationship is new, the auditor is able to remain objective and will not adhere to a client's intervention. Thus, the auditor is said to be independent. Regulators believed that auditor rotation is a solution for auditors to remain independent. In the aftermath of the major corporate collapses, such as Enron and WorldCom, policymakers and regulators have expressed concerns over the lack of auditor independence that might have caused by audit firm tenure and its effects on audit quality. Mandatory audit firm rotation (MAFR) every several years was suggested as solution (PCAOB, 2011) to strengthen independence. The notion of MAFR stems from the perception that long auditor tenure and the comfortable relationship between auditor and client would threaten auditor independence and 
decrease the auditing quality. Several Asian countries have adopted mandatory rotation. Previous research conceptualized tenure differently. For example, Shockley (1981) conceptualized tenure as 'Long' or 'Short'. Recently conducted market based research defined audit tenure by the number of year of audit-client relationship. Carcello and Nagy (2004) and Johnson, Khurana, and Reynolds (2002) specifically defined "short" to be less than three years and "long" to be more than nine years. In Malaysia, the length of audit tenure and the possible effects on auditor independence are still unclear and are not explicitly addressed in any of the relevant Malaysian official documents (Abdul Nasser, Wahid, Nazri, \& Mohammad, 2006), though in the year 2002 the Chairman of the MASB then had announced the intention of the board to make it mandatory to rotate the audit firm once every five years (The Edge, 2002). The current study will define audit tenure as 'More than five years' and 'Less than five years'.

\section{Audit Firm Size and the Auditor's Likelihood of Supporting an Audit Exemption for SMEs}

Previous research has reported that audit firm size influences the auditor's independent judgement. Geiger and Rama (2006) observed a significant difference between clients that are audited by big- 4 and non-big- 4 audit firms with respect to bankruptcy filings after receiving a modified going concern report in the prior year. They found that the clients of big- 4 firms file for bankruptcy less frequently and exhibit higher quality audit reports compared to those of non-big-4 firms. Amake and Okafor (2012) found that although audit firm size has a positive effect on auditors' independence, this relationship was not significant. Regarding the perspectives of accountants and auditors, Salehi and Mansoury (2008) revealed that $70 \%$ (126 participants) of those surveyed did not agree that firm size affects auditors' willingness to report biases. In other words, they believe that firm size has no significant effect on auditors' independence.

In Malaysia, Sori, Mohamad, and Karbhari (2006), Abu Bakar and Ahmad (2009) and Salleh, et al. (2008b) found that audit firm size has a positive and significant effect on auditor independence. Regarding the perspectives of third parties such as bank loan officers, Abu Bakar, et al. (2005) also reported a positive relationship between firm size and the level of auditor independence. Therefore, in our study on audit firm size and the likelihood that an auditor will support an audit exemption for SMEs, we hypothesis that:

H1: Large audit firm will lead to a greater likelihood of supporting the audit exemption. 


\section{Non-audit Services and the Auditor's Likelihood of Supporting an Audit Exemption for SMEs}

One factor associated with the downfall of Enron Corporation was that NAS were being offered in conjunction with audit services. As a result, US regulators passed a new law called the Sarbanes-Oxley Act in 2002. The act prohibited auditors from providing NAS (except for taxation) in conjunction with audit services. In addition, the law requires that the fees charged for NAS must be disclosed in the clients' annual reports. In Malaysia, the MIA By-Law states that a "self-review threat" might be created if audit firms provide both audit and NAS to the same client.

Research conducted by Ahadiat (2011) on British and Australian audit clients concluded that providing non-audit services makes auditors less likely to issue a qualified opinion. Indirectly, this implies that providing NAS might impair auditor independence. In Malaysia, Abu Bakar and Ahmad (2009) and Abu Bakar, et al. (2005) found that accountants and bank loan officers agree that NAS have a significant effect on auditor independence. In addition, Hariri (2009) found that NAS fees have a positive relationship with the impairment of auditor independence. Thus the current study on NAS and the likelihood of an auditor supporting an audit exemption for SMEs hypothesis the following:

H2: Audit firms that provide non-audit services will have a greater likelihood of supporting the audit exemption.

\section{Audit Tenure and the Auditor's Likelihood of Supporting an Audit Exemption for SMEs}

Audit tenure has been studied in association with the collapse of large business empires such as Enron Corporation, WorldCom, etc. The duration of the auditorclient relationship is perceived to influence the auditor's independence and judgement, especially regarding the auditor's opinion of the truth and fairness of the financial statements of client companies and in issuing the audit report. US regulators have recommended "audit rotation" to maintain auditor independence and reliable audit reports. This means that audit firms are not allowed to audit a client's company for an excessive period, as this may affect the auditor's judgement. A relationship that is too long can affect the quality of audit work. Rotation is suggested not only for the audit firm but also for the audit partner. In Malaysia, the MIA has proposed that an audit partner be rotated after having audited a client's company for five years (MIA, 2012). The effectiveness of this practice, however, remains unclear. 
Prior research has reported mixed evidence regarding audit tenure and auditor independence. Auditors tend to issue more qualified reports in the early period oftheir tenure with a client (and hence if not too long). For example, the qualified reports means that the auditor cannot give a true and fair view about the company's financial report or in other words, the auditors are unable to provide the opinion that the financial statement is correct. Meyer, Rigsby, and Boone (2007) and Geiger and Raghunandan (2002) found that a long audit tenure has a positive relationship with issuing more unqualified reports relative to a short audit tenure. However, Chiang and Lin (2012), in a study on Taiwan, found that audit tenure alone has no impact on the likelihood of an auditor issuing an unqualified report. This means that audit tenure is also influenced by other factors, such as the personal interests of auditors that combined with a long audit tenure will affect the auditors' independence in issuing an audit report.

Amake and Okafor (2012) found that audit tenure has a positive but not significant relationship with auditor independence. The authors explain this lack of significance through the auditors' honouring the trust and commitment that they received from the client. Hariri (2009) found that audit tenure has no significant relationship with auditor independence, which contradicts Abu Bakar and Ahmad (2009)'s findings. The latter found that audit tenure has a negative relationship with an auditor's independence. Therefore, the current study on audit tenure and the likelihood that an auditor will support an audit exemption for SMEs hypothesises that:

H3: Short audit tenure will lead to a higher likelihood of supporting the audit exemption for SMEs.

\section{RESEARCH METHOD}

In this study, the analyses are conducted at the individual level, thus the unit of analysis is the individual auditor. The sample was chosen from the population firms registered as MIA members. Based on the information provided by the MIA, as of 2013 there were 1239 registered member firms that provide audit services.

The data for this study was collected using questionnaires which consists of two parts. Part A consists of the background information about the respondents and part $\mathrm{B}$ consists of eight cases. The questionnaire for this study was developed by the researchers. A pre-test of the questionnaire was conducted using five auditors from the MIA list. The purpose of the pre-test is to ensure that the questionnaire is clear and suitable for respondents to answer. The respondents found the questionnaires to 
be clear. The five respondents in the pre-test have been excluded for the empirical research in order to avoid any bias data.

A total of 600 questionnaires was distributed with self-addressed returned envelopes to randomly chosen audit firms from the list provided by MIA. Finally, 79 usable responses were received which gave a $13 \%$ of response rate. According to Sekaran and Bougie (2010), the sample size has to be ranged between 30 to 500 respondents to ensure that the analysis is acceptable and can be tested.

An experimental design is used to achieve the research aims of examining the "effect" of the three variables on the perceptions of auditors' independence. An experiment involves a researcher manipulating one or more variables to determine the effect of this manipulation on another variable (Kirk, 2013). In essence, the independent variables in this study will be tested at certain levels, namely the treatment levels, to determine their effects on the dependent variable.

The current study assesses the effects of three independent variables, namely audit firm size, the provision of NAS and audit tenure, at two levels as shown in Table 2 . The study uses a $2 \times 2 \times 2$ within- subjects design. Each respondent will have to evaluate eight scenarios (see Table 1) that manipulate the independent variables as described in Table 3. The hypothetical case involves an auditor auditing an SME with the following characteristics:

1. SME size

- Annual Turnover of between RM400,000 and RM500,000 with 5 permanent employees.

2. Nature of business and industry

- Retail and services business

3. Other Characteristics commonly faced by SMEs

- No or improper segregation of duties

- Improper record keeping

- Lack of internal control and monitoring in inventory and the collection of sale proceeds

4. Other hypothetical scenario

- An auditor assigned to conduct audit faces the dilemma of whether to proceed with an audit of the SME 
In other words, a scenario in which a senior auditor faces a dilemma when auditing an SME based on certain SME characteristics will be introduced prior to the manipulation of the variables. The scenario portrays a dilemma faced by the senior auditor concerning internal control issues. In the experimental design, this acts as the control variable, establishing a uniform condition for the respondents to assume before proceeding to complete the set of questions posed in the questionnaire. Respondents are asked to assess the actions of the auditor based on the background of the company provided in paragraphs 1 and 2; the conflict described in paragraph 3; and the manipulated variables described in paragraph 4 .

Table 2

Eight Scenarios/Cases

\begin{tabular}{|c|c|c|c|c|c|c|}
\hline \multirow{2}{*}{ Cases } & \multicolumn{2}{|c|}{ Audit Tenure } & \multicolumn{2}{|c|}{ Firm Size } & \multicolumn{2}{|r|}{ NAS } \\
\hline & $>5$ years & $<5$ years & $>5$ employees & $<5$ employees & Provides & Does not provide \\
\hline Case 1 & $x$ & & $x$ & & $x$ & \\
\hline Case 2 & $x$ & & & $x$ & $x$ & \\
\hline Case 3 & $x$ & & $x$ & & & $x$ \\
\hline Case 4 & $x$ & & & $x$ & & $x$ \\
\hline Case 5 & & $x$ & $x$ & & $x$ & \\
\hline Case 6 & & $\times$ & & $\times$ & $x$ & \\
\hline Case 7 & & $x$ & $x$ & & & $x$ \\
\hline Case 8 & & $x$ & & $x$ & & $x$ \\
\hline
\end{tabular}

Table 3

Measurement of Independent Variables

\begin{tabular}{ll}
\hline Independent Variables & Treatment Levels \\
\hline Audit Firm Size & $\begin{array}{l}\text { a. More than five employees } \\
\text { b. Fewer than five employees }\end{array}$ \\
Non-Audit Services & $\begin{array}{l}\text { a. Provides NAS } \\
\text { b. Does not provide NAS }\end{array}$ \\
Audit Tenure & $\begin{array}{l}\text { a. More than five years } \\
\text { b. Fewer than five years }\end{array}$ \\
\hline
\end{tabular}

Meanwhile, the dependent variable for this study is perceptions of auditors' independence. An auditor dilemma scenario was used to examine auditor independence, proxy by 'likelihood to agree for audit exemption on SMEs. Previous studies on auditor-client conflict have used a scenario to evaluate if an 
auditor would accede or oppose a client's resolution such as $\mathrm{Gul}(1989,1991)$; Knapp (1985) and Patel and Psaros (2000).

The example of the one of the eight case scenarios in the questionnaire is illustrated as below.

\section{CASE 1:}

\section{Background Information}

Elite Lightings Sdn Bhd (ELSB) is a family-owned Small and Medium Enterprise (SME) that specializes in home and commercial lighting design and services. ELSB is located in Raub, Pahang and has been in operation for the past 15 years. The firm's average annual turnover ranges between RM400,000.00 to RM500,000.00. Presently there are 5 permanent employees in the firm.

The owners have little financial knowledge. In addition, due to the small number of employees, ELSB often faced difficulty in segregation of duties. Transaction records were kept but occasionally, several errors were detected by the manager upon inspection. The store clerks often find inventory review of stocks difficult due to improper inventory record. The manager believes items were taken out from the store for installation work but there were no proper record and monitoring of physical stocks by the employees. Collection of sales proceeds was slow at times due to the present manner of record keeping.

Mr Sam is a senior auditor in Ahmad \& Associates. Mr Sam has been assigned to conduct the audit and taxation for ELSB this year. Mr Sam has read some articles pertaining to the topic of audit exemption of SMEs in the 2012 issue of Accountants Today. After going through the records of ELSB, Mr Sam is hesitant whether he should proceed with the audit.

\section{$\underline{\text { Additional Information }}$}

Ahmad \& Associates is an audit firm with a total number of more than 5 employees. Ahmad \& Associates has been providing audit services to ELSB for more than 5 years. In addition to audit services, Ahmad \& Associates also offer other non audit services besides taxation. 


\section{Instruction:}

Based on the scenario in the background and additional information above, please circle the most appropriate response to the questions below.

\section{Question 1:}

In your opinion, how likely would Mr Sam proceed with the audit of Elite Lightings Sdn Bhd (ELSB)/ not exempt ELSB from being audited?

Very low likelihood

$$
1
$$$$
2
$$$$
3
$$$$
4
$$$$
\begin{array}{lll}
5 & 6 & 7
\end{array}
$$

Very high likelihood

\section{Question 2:}

Assume you are the auditor for Elite Lightings Sdn Bhd how likely would you proceed with the audit of the firm/ not exempt ELSB from being audited?

Very low likelihood

12

34

$5 \quad 6 \quad 7$

Very high likelihood

\section{RESULTS}

The GLM (Repeat Measures) is used to test the hypotheses. The GLM (Repeat Measures) is a statistical tool in SPSS that is able to detect the effects of categorical independent variables on a continuous dependent variable. This includes detecting the main and interaction effects of independent variables on the dependent variable. An ANOVA was conducted to address the research questions.

A total of 79 useable questionnaires were considered in the analysis. The respondent profiles are summarised in Table 4 . Regarding age, only $17.7 \%$ of the respondents are considered young, that is, less than 25 years old, while only slightly more than $5 \%$ are above 55 years of age. Nearly half, $41.8 \%$, of the respondents are between 26 and 35 years old, and $70.9 \%$ of the respondents are in the 26-45 age category. Among the 79 respondents, $41.8 \%$ are male and $58.2 \%$ are female. Regarding the 
current positions of the respondents, $46.1 \%$ are junior/senior auditors, $27.6 \%$ are audit managers, more than one-sixth (or 17.1\%) and slightly less than one-tenth (or $9.2 \%$ ) are partners and audit supervisors.

Table 4

Respondent profiles

\begin{tabular}{|c|c|c|c|}
\hline Items & & $n$ & $\%$ \\
\hline \multirow[t]{5}{*}{ Age } & $<25$ years old & 14 & 17.7 \\
\hline & 26-35 years old & 33 & 41.8 \\
\hline & $36-45$ years old & 23 & 29.1 \\
\hline & $46-55$ years old & 5 & 6.3 \\
\hline & Above 55 years old & 4 & 5.1 \\
\hline \multirow[t]{2}{*}{ Gender } & Male & 33 & 41.8 \\
\hline & Female & 46 & 58.2 \\
\hline \multirow[t]{6}{*}{ Highest Education } & Diploma & 1 & 1.3 \\
\hline & Bachelor's Degree & 35 & 44.3 \\
\hline & Master's Degree & 3 & 3.8 \\
\hline & $\mathrm{PhD} /$ Doctorate & 0 & 0.0 \\
\hline & Professional Qualification & 39 & 49.4 \\
\hline & Other Qualification & 1 & 1.3 \\
\hline \multirow[t]{6}{*}{ Professional Certificates } & MICPA & 7 & 8.9 \\
\hline & CIMA & 1 & 1.3 \\
\hline & CPA (Australia) & 8 & 10.1 \\
\hline & ACCA & 23 & 29.1 \\
\hline & Others & 4 & 5.1 \\
\hline & Not Applicable & 36 & 45.6 \\
\hline \multirow[t]{4}{*}{ Current Position } & Junior/Senior & 35 & 46.1 \\
\hline & Audit Supervisor & 7 & 9.2 \\
\hline & Audit Manager & 21 & 27.6 \\
\hline & Partner & 13 & 17.1 \\
\hline
\end{tabular}

A large proportion (49.4\%) of the respondents have a professional qualification, while a similar percentage $(44.3 \%)$ holds a Bachelor's degree. While none of the respondents have SPM/STPM qualification and only one has a Diploma, none of the respondents are $\mathrm{PhD} /$ Doctorate holders. Among the professional certifications that the respondents possess, the plurality (29.1\%) of the respondents have an ACCA qualification, $10.1 \%$ and $8.9 \%$ of the respondents have CPA (Australia) and MICPA 
qualifications respectively, and only one respondent has a CIMA certificate. The reason why there is a low number of auditors with a low professional qualification is due to the fact that in Malaysia, one of the pathways to be an auditor is to have a Bachelor of Accounting degree by an approved institution accredited by MIA and possess three years relevant working experience. Nearly half of respondents have taken this route. Furthermore, most of the respondents are from the senior group because most of the small firms normally have partners and junior and senior level employees only.

\section{Descriptive Statistics}

Table 5

Means of different scenarios

\begin{tabular}{clc}
\hline Case & Scenarios & Mean \\
\hline 1 & $<5$ firm employees, $<5$ tenure years, do not offer NAS & 4.02 \\
2 & $<5$ firm employees, $<5$ tenure years, offer NAS & 4.22 \\
3 & $<5$ firm employees, $>5$ tenure years, do not offer NAS & 4.21 \\
4 & $<5$ firm employees, $>5$ tenure years, offer NAS & 4.17 \\
5 & $>5$ firm employees, $<5$ tenure years, do not offer NAS & 4.39 \\
6 & $>5$ firm employees, $<5$ tenure years, offer NAS & 4.46 \\
7 & $>5$ firm employees, $>5$ tenure years, do not offer NAS & 4.48 \\
8 & $>5$ firm employees, $>5$ tenure years, offer NAS & 4.54 \\
\hline
\end{tabular}

Table 5 presents the mean likelihood of supporting an audit exemption for each of the eight scenarios. From the tabulated values, the highest likelihood of supporting an audit exemption is exhibited in case 8 (mean of 4.544), where the scenario includes large firm size, long audit tenure and firms that offer NAS. The lowest likelihood is exhibited in case 1 (mean of 4.019), where the scenario is the opposite of that in case 8, namely, small firm size, short audit tenure and firms that do not offer non-audit services. By examining the differences in mean likelihood (taking case 8 as the reference), case 4 (mean of 4.171), featuring small firm size, has the largest mean difference with case 8 , followed by case 6 (mean of 4.456), featuring short audit tenure, and case 7 (mean of 4.475), which concerns firms that do not offer non-audit services. This finding suggests that firm size is the most important among the three factors considered in influencing the likelihood of supporting an audit exemption. The small difference in the mean between cases 8 and 6 and between cases 8 and 7 suggests that the length of audit tenure and firm provision of NAS may not be important factors influencing the likelihood of supporting an audit exemption. 


\section{Comparison of the Independent Variables}

Another initial method of analysis that can be employed to determine the possible influence of certain factors on the likelihood of supporting an audit exemption is a 2-sample t-test. However, note that for each respondent, the eight scenarios are dependent as four scenarios relate to small firms and the remaining four scenarios relate to large firms. Because all statistical tests, including a paired t-test, require independent samples, the likelihoods obtained in the four scenarios involving small firms and those involving large firms are averaged. A similar procedure is conducted when testing mean differences in likelihoods for firms with different lengths of audit tenure and the mean differences in the likelihoods for firms with different NAS provision.

Table 6

Paired t-test, factors vs. likelihood

\begin{tabular}{llcccccc}
\hline Pairs & & $\mathrm{n}$ & Mean & Mean difference & $\mathrm{t}$ & $\mathrm{df}$ & $\mathrm{p}$-value \\
\hline Pair 1 & Small Firm & 79 & 4.155 & -0.312 & -4.35 & 78 & $* * * 0.000$ \\
& Large Firm & 79 & 4.467 & & & & \\
Pair 2 & Short Tenure & 79 & 4.272 & -0.078 & -0.75 & 78 & 0.454 \\
& Long Tenure & 79 & 4.350 & & & & \\
Pair 3 & Offers NAS & 79 & 4.348 & 0.074 & 1.30 & 78 & 0.197 \\
& Does Not Offer NAS & 79 & 4.274 & & & & \\
\hline
\end{tabular}

Note: $* \mathrm{p}<0.05, * * \mathrm{p}<0.01, * * * \mathrm{p}<0.001$

From Table 6, the means of the likelihood of supporting an audit exemption do not appear to differ substantially between small and large firms (4.155 and 4.467, respectively). However, and surprisingly, the paired t-test yields a significant result at the $5 \%$ level (t-statistic of -4.35 with a corresponding p-value of 0.000 ), indicating that the two means are statistically different. Here, the results imply that the likelihood that auditors at large firms will support an audit exemption is significantly higher than the likelihood that auditors at small firms will do so. In brief, firm size affects the likelihood of supporting an audit exemption.

Similarly, the means of the likelihood of supporting an audit exemption do not appear to differ substantially between firms with a short audit tenure and firms with a long audit tenure (4.272 and 4.350, respectively). Unsurprisingly, the paired t-test does not yield a significant result (t-statistic of -0.75 with a corresponding p-value of 0.454), indicating the two means are not statistically different. Thus, the results imply that the likelihood that auditors at firms with a short audit tenure 
and those at firms with a long audit tenure will support an audit exemption can be regarded as the same. At this stage, the length of audit tenure cannot be considered a factor affecting the likelihood of supporting an audit exemption.

Regarding firm provision of NAS, the likelihood of supporting an audit exemption does not appear to substantially differ between firms with respect to whether they offer NAS (4.348 and 4.274 for firms that offer and do not offer NAS, respectively). The result of the paired t-test (t-statistic of 1.30 with a corresponding $\mathrm{p}$-value of 0.197) supports this observation, implying that auditors from these two types of firms have the same likelihood of supporting an exemption. In brief, firm provision of NAS is also not a factor in determining auditor support for an audit exemption.

\section{Hypothesis Testing}

Table 7

Multivariate main effect of firm size, non-audit services and audit tenure on an auditor's support for an audit exemption

\begin{tabular}{lcccc}
\hline Source & F & df & p-value & Partial Eta Squared \\
\hline Firm Size & 23.05 & 1 & $* * * 0.000$ & 0.230 \\
Non-audit Services & 0.38 & 1 & 0.539 & 0.005 \\
Audit Tenure & 0.46 & 1 & 0.498 & 0.006 \\
\hline
\end{tabular}

Note: ${ }^{*} \mathrm{p}<0.05,{ }^{* *} \mathrm{p}<0.01,{ }^{* * *} \mathrm{p}<0.001$

Regarding the tabulated values in Table 7, the F-statistic (23.05) and the corresponding significance level (p-value) of 0.000 suggests that there is a statistically significant difference between the likelihood of supporting an audit exemption among auditors at large firms (more than five employees) and that for auditors at small firms (fewer than five employees). Despite the significance of audit firm size as a factor determining support for an audit exemption, the magnitude of partial eta squared is rather small (0.230), indicating that the strength of association between firm size and the likelihood of supporting an audit exemption is relatively weak.

Meanwhile, regarding firm provision of NAS, the F statistic of 0.38 with a corresponding $\mathrm{p}$-value of 0.539 suggests that the null hypothesis of $\mathrm{H} 3$ stating that firm provision of NAS does not influence the likelihood of supporting an audit exemption cannot be rejected. This implies that there is no evidence to support the hypothesis that firm provision of NAS influencing the likelihood of supporting 
an audit exemption. The insignificance of the main effect of the firm provision of NAS is supported by the very small magnitude of partial eta squared of 0.005 .

However, regarding the length of audit tenure as the main effect, the F statistic of 0.46 with a corresponding p-value of 0.498 indicates that the null hypothesis of $\mathrm{H} 2$ stating that audit tenure does not influence the likelihood of supporting an audit exemption cannot be rejected. This finding implies that there is no sufficient evidence to support the claim that the length of audit tenure is a significant factor influencing the likelihood of supporting an audit exemption. The result suggests the likelihood of supporting an audit exemption when the length of audit tenure is less than five years (short audit tenure) is not statistically significantly different from the likelihood of supporting an audit exemption when the length of audit tenure is more than five years (long audit tenure). The insignificance of length of audit tenure as a determinant of support for an audit exemption is further supported by the very small magnitude of the partial eta squared of 0.006 , indicating that the association between the length of audit tenure and the likelihood of supporting an audit exemption is very weak.

\section{DISCUSSION OF FINDINGS}

H1 was supported at the 5\% significance level. Therefore, the study concludes that working at a large audit firm will lead to a higher likelihood of supporting an audit exemption compared to an individual at a smaller audit firm. This is consistent with the findings reported by Abu Bakar and Ahmad (2009); Amake and Okafor (2012) and Shockley (1981). The larger the firm size is, the greater the tendency to support an audit exemption. This could be because larger audit firms have the resources to provide NAS and have greater opportunities to provide audit services and NAS to other audit firms than do small audit firms. This is generally the argument advanced for why SMPs do not support an audit exemption, as they are of the opinion that it would adversely affect their revenue. The paired t-tests revealed that there is a significant difference between auditors from small and large audit firms in this respect.

The study found that working at firms that provide NAS does not affect the likelihood of supporting an audit exemption. Thus $\mathrm{H} 2$ is rejected. This is consistent with the findings of Goldman and Barlev (1975), who suggested that providing NAS would increase the auditor's independence, as most NAS are non-routine and that the auditor would directly benefit the client firm when conducting his audit work. Thus, it would not be an issue to simultaneously provide NAS and an audit. However findings by Abu Bakar and Ahmad (2009); Hariri (2009) and 
Shockley (1981) indicated a significant relationship between NAS and auditor independence. They concluded that simultaneously providing NAS and an audit impair the auditor's independence. The different findings in this regard in the present study may result from the different measurement methods employed.

The professional independence of an auditor in Malaysia is considered to be impaired if the total fees arising from providing NAS to a client represent $20 \%$ or more of the audit firm's total annual fees for two or more consecutive years (Ahmad, Shafie, \& Yusof, 2006). However the MIA By-Law does not state a maximum limit for NAS received from a single client. This could be because the MIA is of the opinion that there is no conflict between offering NAS and an audit. In practice, audits and NAS services are offered by different divisions of the audit firms and are headed by different auditors, and thus audit firms might be of the opinion that providing both types of services would not impair their independence. Paired t-tests indicated that there is no significant difference between firms that provide and do not provide NAS. Furthermore, auditors will charge lower nonaudit fees if the firm provides audit services and NAS to the same client (Craswell \& Guest, 2000).

The study found that audit tenure does not have an effect on the likelihood that an auditor will support an audit exemption for SMEs. Thus, H3 was rejected. This could be because audit firms with a short audit tenure have yet to establish a good relationship with the SME client company and are not familiar with the SME's systems and problems. Such audit firms would like to better understand the SME client company and realise that auditing services could represent an additional source of revenue for their companies. This also implies that a short audit tenure does not necessarily mean that the audit firm is more independent. The findings of this study are consistent with those of previous studies reporting that audit tenure does not affect auditor independence. Through paired t-tests, the present study found that there is no significant difference between a short and long audit tenure. This is consistent with Hariri (2009) and Carcello and Nagy (2004). However, in contrast, Abu Bakar and Ahmad (2009) and Meyer et al. (2007) found that a long audit tenure will improve audit quality and improve auditor independence. The difference between these findings could be due to the different research designs employed in conducting the studies. This study adapted an experimental design which focus on the cause and effect relationship by manipulating the factors while past studies utilised a correlational study.

Auditing standards require that the auditors of a given client company be rotated every five years (MIA By-Law section 290: Independence and audit review and engagement). However, as found by Mohamed, Ismail, Nazri, and Hariri (2007), 
this is not followed in practice - companies in Malaysia tend to retain their auditors for more than five years. The findings of the study accord with those of Shockley (1981) and Teoh and Lim (1996), who reported that tenure did not impair independence. In practice, a single auditor continues to perform audit services but rotates auditors after five years. In Malaysia, although there is no mandatory audit firm rotation, there is mandatory audit partner rotation which requires that partners rotate every five years when auditing PLCs and public interest entities (MIA, 2012; Siregar, Fitriany Amarullah, Wibowo, \& Anggraita, 2012).

In summary, only the size of the audit firm was found to affect the likelihood that an auditor supports an audit exemption for SMEs. The results of this study do not support the hypotheses that NAS and audit tenure affect an auditor's likelihood of supporting an audit exemption. This indicates that small audit firms do not support an audit exemption for SMEs because they might believe that this represents their main source of revenue. It is also possible that such audit firms lack the necessary skills, knowledge and competencies to devote greater attention and focus to nonaudit services, such as consultancy and taxation (Haron, et al., 2010).

\section{CONCLUSIONS AND LIMITATIONS}

This study found that large audit firms tend to support an audit exemption for SMEs and that small audit firms hold the opposite opinion. This could be because small audit firms lack the necessary skills, knowledge and competencies to offer non-audit services. Some of the explanations cited in the past literature include a lack of resources to train staff. If this is the issue, a possible remedy would be for the MIA to recommend that small audit firms merge or expand their capacity by increasing the size of their staff. For example, audit firms could collaborate with legal firms, and when a client requests legal work, the small audit firm could channel the work to legal experts working for their audit firm. There could also be a consortium or a network of small audit firms which would "pass on" work to other members in the consortium if the service requested is not available in a particular audit firm.

Although issue of audit exemption has been the subject of much debate in the literature, there is little empirical evidence on the issue. As the issue of this study had examine using an experimental design which is different from past studies, it is able to enhance the knowledge of scholars and provide the empirically evidence in the field of study. 
As in other research, this study has limitations. The principal limitation of the study is its small sample size which might be attributable to the length of the questionnaire. Although the sample size in the study was 79 , this is sufficient to meet the study's objectives (according to Roscoe's rule of thumb), but ideally, a larger sample size would have been obtained. The sample also includes big-four firms, but in reality, firms outside of the big four typically audit SMEs. However, the proportion of large firms is quite small in this study. Nevertheless, this is acceptable, as this study merely aimed to examine the perceptions of all auditors with respect to the issue of audit exemption. Future studies could only include small audit firms and conduct interviews to obtain more detailed reasons that such firms do not support an audit exemption.

\section{REFERENCES}

Abang, S. (2013). Boosting SMPs through supporting SMEs? Accountants Today, 26, $48-49$.

Abdul Nasser, A. T., Wahid, E. A., Nazri, S. N. F. S. M., \& Mohammad, H. (2006). Auditor-client relationship: the case of audit tenure and auditor switching in Malaysia. Managerial Auditing Journal, 21(7), 724-737. https://doi. org/10.1108/02686900610680512

Abu Bakar, N. B., Abdul Rahman, A. R., \& Abdul Rashid, H. M. (2005). Factors influencing auditor independence: Malaysian loan officers' perceptions. Managerial Auditing Journal, 20, 804-822. https://doi.org/10.1108/02686900510619665

Abu Bakar, N. B., \& Ahmad, M. (2009). Auditor independence: Malaysian accountants' perceptions. International Journal of Business and Management, 4(12), 129-141. https://doi.org/10.5539/ijbm.v4n12p129

ACCA. (2010). Reshaping the audit for the new global economy. London: The Association of Chartered Certified Accountants (ACCA).

Ahadiat, N. (2011). Association between audit opinion and provision of non-audit services. International Journal of Accounting and Information Management, 19(2), 182193. https://doi.org/10.1108/18347641111136463

Ahmad, A. C., Shafie, R., \& Yusof, N. Z. M. (2006). The provision of non-audit services, audit fees and auditor independence. Asian Academy of Management Journal of Accounting And Finance, 2(1), 21-40.

Amake, C. C., \& Okafor, C. (2012). Auditors Independence, Auditors ' Tenure and Audit Firm Size In Nigeria. Journal of Finance and Accounting, 3, 137-142.

Arruñada, B. (2011). Mandatory accounting disclosure by small private companies. European Journal of Law and Economics, 32(3),377-413. https://doi.org/10.1007/ s10657-010-9145-3

Audit Oversight Board. (2014). Sectorial Dialogue with Audit Firms. Regulatory Updates and Sharing of Best Practices, 10 November, Securities Commission Malaysia. Retrieved December 1, 2015 from http://www.sc.com.my 
Beattie, V., \& Fearnley, S. (2002). Auditor Independence and Non-Audit Services: A Literature Review. Unpublished manuscript.

Beaver, G., \& Prince, C. (2004). Management, strategy and policy in the UK small business sector: A critical review. Journal of Small Business and Enterprise Development, 11(1), 34-49. https://doi.org/10.1108/14626000410519083

Carcello, J. V., \& Nagy, A. L. (2004). Audit firm tenure and fraudulent fnancial reporting. Journal of Practice and Theory, 23, 55-69.

Chan, W. M. (2012). Exemption of annual audit for small companies: A review. Pertanika Journal of Social Sciences \& Humanities (JSSH), 20(1), 1-10.

Chiang, H. T., \& Lin, S. L. (2012). Effect of auditor's judgment and specialization on their differential opinion between semiannual and annual financial reports. Global Journal of Business Research, 6(4), 1-23.

Chung, S., \& Narasimhan, R. (2001). Perceived value of mandatory audits of small companies. Journal of Managerial Auditing, 16, 120-123. https://doi.org/10.1108/ 02686900110385551

Collis, J. (2010). Audit exemption and the demand for voluntary audit: A comparative study of the UK and Denmark. International Journal of Auditing, 14(2), 211-231. https://doi.org/10.1111/j.1099-1123.2010.00415.x

Collis, J., \& Jarvis, R. (2002). Financial information and the management of small private companies. Journal of Small Business and Enterprise Development, 9(2), 100110. https://doi.org/10.1108/14626000210427357

Craswell, A. T., \& Guest, R. S. (2000). Price and demand effects in the market for audit services: Working paper, University of Sydney and Griffith University, Australia, Queensland.

DeAngelo, L. E. (1981). Auditor size and audit quality. Journal of Accounting and Economics, 3(3), 183-199. https://doi.org/10.1016/0165-4101(81)90002-1

Donaldson, L., \& Davis, J. H. (1991). Stewardship theory or agency theory: CEO governance and shareholder returns. Australian Journal of management, 16(1), 49-64. https://doi.org/10.1177/031289629101600103

Dopuch, N., King, R. R., \& Schwartz, R. (2003). Independence in appearance and in fact: An experimental investigation. Contemporary Accounting Research, 20(1), 79114. https://doi.org/10.1506/9B5D-HLLP-BBQE-8N3F

Farrugia, K. J., \& Baldacchino, P. J. (2005). Qualified audit opinions in Malta. Managerial Auditing Journal, 20(8), 823-843. https://doi.org/10.1108/02686900510619674

Firth, M. (1997). The provision of non-audit services and the pricing of audit fees. Journal of Business Finance \& Accounting, 24, 511-525. https://doi.org/10.1111/14685957.00118

Geiger, M. A., \& Raghunandan, K. (2002). Auditor tenure and audit reporting failures. Journal of Practice and Theory, 21, 67-78. https://doi.org/10.2308/ aud.2002.21.1.67

Geiger, M. A., \& Rama, D. V. (2006). Audit firm size and going-concern reporting accuracy. Accounting Horizons, 20(1), 1-17. https://doi.org/10.2308/acch.2006.20.1.1

Goddard, A. R., \& Masters, C. (2000). Audit committees, Cadbury Code and audit fees: an empirical analysis of UK companies. Managerial Auditing Journal, 15(7), 358371. https://doi.org/10.1108/02686900010344638 
Goldman, A., \& Barlev, B. (1975). The auditor-firm conflict of interests: Its implications for independence: A reply. Accounting Review, 50(4), 857-859.

Gul, F. A. (1989). Bankers' perceptions of factors affecting auditor independence. Accounting, Auditing \& Accountability Journal, 2(3). https://doi.org/10.1108/ 09513578910132303

Gul, F. A. (1991). Size of audit fees and perceptions of auditors'ability to resist management pressure in audit conflict situations. Abacus, 27(2), 162-172. https://doi. org/10.1111/j.1467-6281.1991.tb00264.x

Haniffa, R. (2006). The influence of "culture" on accounting and auditing in Malaysia. Managerial Auditing Journal, 21(1), 684-701.

Hariri, H. (2009). The Effect of Non-Audit Service Fees, Audit Tenure, Audit Competition and Professionalism of Auditors' Independence: The Perception of External Auditors and Government Auditors. Unpublished PhD, Universiti Sains Malaysia, Penang, Malaysia.

Haron, H., Ismail, I., Yahya, S., Khalid, S. N. A., \& Ganesan, Y. (2010). Cases of successful malaysian small and medium enterprises (smes): Does business advisory services help? Penang: Univeristi Sains Malaysia, funded by Malaysian Accountancy Research and Education Foundation (MAREF)

Jensen, M. C., \& Meckling, W. H. (1976). Theory of the firm: Managerial behavior, agency costs and ownership structure. Journal of financial economics, 3(4), 305-360. https://doi.org/10.1016/0304-405X(76)90026-X

Johnson, E., Khurana, I. K., \& Reynolds, J. K. (2002). Audit-Firm tenure and the quality of financial reports. Contemporary Accounting Research, 19(4), 637-660. https://doi.org/10.1506/LLTH-JXQV-8CEW-8MXD

Kamarudin, N., Abidin, Z. Z., \& Smith, M. (2012). Audit exemption among SMEs in Malaysia. Asian Review of Accounting, 20(2), 152-162. https://doi.org/ $10.1108 / 13217341211242196$

Kirk, R. E. (2013). Experimental design, procedures for the behavioral science. (4th ed.). USA: SAGE Publications. https://doi.org/10.4135/9781483384733

Knapp, M. C. (1985). Audit conflict: An empirical study of the perceived ability of auditors to resist management pressure. [Article]. Accounting Review, 60(2), 202.

Koo, C. M., \& Sim, H. S. (1999). On the role conflict of auditors in Korea. Accounting, Auditing \& Accountability Journal, 12(2), 206-219. https://oi.org/10.1108/ 09513579910270110

Langli, J. C., \& Svanström, T. (2013). Audits of private firms. Centre for Corporate Governance Research.

Lee, E. (2002). Merge, Acquire and Prosper. Akauntan Nasional, 15(6), 12-17.

McKinley, S., Pany, K., \& Reckers, P. M. J. (1985). An examination of the influence of CPA firm type, size, and MAS provision on loan officer decisions and perceptions. Journal of Accounting Research, 23(2), 887-896. https://doi.org/10.2307/2490846

Md. Ali, A., Sahdan, M. H., Harun Rasit, M. H., \& Teck, H. L. (2008). Audit specialisation in Malaysia. International Journal of Business and Management, 3(3), 91-99.

Meyer, M. J., Rigsby, J. T., \& Boone, J. (2007). The impact of auditor-client relationships on the reversal of first-time audit qualifications. Managerial Auditing Journal, 22, 53-79. https://doi.org/10.1108/02686900710715648 
MIA. (2012). By-Laws (On Professional Ethics, Conduct And Practice) of The Malaysian Institute of Accountants Kuala Lumpur: MIA.

Mohamed, W. A. W., Ismail, A. H., Nazri, S. N. F. S. M., \& Hariri, H. (2007). An investigation of auditor and client tenure in Malaysian public listed companies Corporate Integrity Framework Research Monograph. Kuala Lumpur: Malaysian Institute of Integrity.

Patel, C., \& Psaros, J. I. M. (2000). Perceptions of external auditors' independence: Some cross-cultural evidence. The British Accounting Review, 32(3), 311-338. https://doi.org/10.1006/bare.2000.0138

PCAOB. (2011). Concept release on auditor independence and audit firm rotation. Washington, D.C.: Public Company Accounting Oversight Board.

Power, M. (1997). The audit society: Rituals of verification: Oxford: Oxford University Press.

Salehi, M., \& Mansoury, A. (2008). Firm size, audit regulation and fraud detection: Empirical evidence from Iran. Journal of Management, 4, 5-19.

Salleh, A., Che Rose, R., Kumar, N., \& Jaafar, S. (2008a). Auditors perceptions on obliteration of mandatory annual audit: An empirical study. Journal of Finance and Economics, 14, 61-67.

Salleh, A., Che Rose, R., Kumar, N., \& Jaafar, S. (2008b). External auditors' viewpoint on audit exemption of small companies in Malaysia. ICFAI Journal of Audit Practice, 5(4), 22-34.

Salleh, A., Che Rose, R., Kumar, N., \& Lu, C. P. (2007). Readiness in meeting globalization challenges: A case of accounting firms in Malaysia. Journal of Social Sciences 3(4), 176-184. https://doi.org/10.3844/jssp.2007.176.184

Sekaran, U., \& Bougie, R. (2010). Research methods for business: A skill building approach (5th ed.). UK: John Wiley \& Sons Ltd.

Shockley, R. A. (1981). Perceptions of auditors' independence: An empirical analysis. Accounting Review, 56(4), 785.

Siregar, S. V., Fitriany Amarullah, Wibowo, A., \& Anggraita, V. (2012). Audit tenure, auditor rotation, and audit quality: The case of Indonesia. Asian Journal of Business and Accounting, 5(1), 55-74.

Sori, Z. M., Mohamad, S., \& Karbhari, Y. (2006). Perceived auditor independence and size of audit firm. Universiti Putra Malaysia, Selangor, Malaysia.

Surail, A. K., Ayoib, C. A., \& Hariri, H. (2007). Competition in the market for audit services. Evidence from Malaysia. Paper presented at the 8th Asian Acadamic Accounting Association, Universitas Gadjah Mada, Yogyakrta, Indonesia.

Tabone, N., \& Baldacchino, P. J. (2003). The statutory audit of owner-managed companies in Malta. Managerial Auditing Journal, 18(5), 387-398. https://doi. org/10.1108/02686900310476855

Teoh, H. Y., \& Lim, C. C. (1996). An empirical study of the effects of audit committees. Journal of International Accounting, Auditing \& Taxation, 5(2), 231. https://doi. org/10.1016/S1061-9518(96)90007-5

The Edge. (2002). Column 4th. The Edge, 5 November, 2-3. 